\title{
Analisis Risiko Produk Alat Pelindung Diri (APD) Pencegah Penularan COVID-19 untuk Pekerja Informal di Indonesia
}

\author{
Yansen Theopilus, Thedy Yogasara, Clara Theresia, Johanna Renny Octavia \\ Pusat Studi Ergonomi, Jurusan Teknik Industri, Universitas Katolik Parahyangan \\ Jl. Ciumbuleuit 94, Bandung 40141 \\ Email: yansen_theopilus@unpar.ac.id, thedy@unpar.ac.id, claratheresia@unpar.ac.id, johanna@unpar.ac.id
}

\begin{abstract}
The Coronavirus Disease of 2019 (COVID-19) that is transmitted through the human respiratory system has a very high infection rate worldwide, including Indonesia. To cut off this outbreak, Indonesia has implemented some social distancing strategies that have an impact on the significant decrease of economic growth rate and the increase of poverty rate. To meet basic needs, people should continue their work in the middle of COVID19 fear. Informal workers are among the most vulnerable groups to COVID-19 transmission because they frequently interact with the outsiders and find it difficult to comply with the health protocols. One way to prevent the COVID-19 transmission is the use of Personal Protective Equipment (PPE) such as masks, face shields, and gloves. Although these products to some degree are effective in preventing transmission, several risks that may endanger its users, such as incorrect or excessive use, incorrect maintenance, bad PPE design, and others. Therefore, this research aims to analyze the risks of the COVID-19 PPE and review the prevention recommendations for these risks. Risk analysis was carried out using the Failure Mode and Effect Analysis (FMEA) to analyze the use of masks, face shields, and gloves for the context of general informal workers in Indonesia. There are 5 aspects analyzed: product design, preparation for use, use, storage, and disposal. Based on the analysis, there are 10 mask risks, 15 face shield risks, and 12 gloves risks that need to be considered by informal workers and PPE designers and manufacturers as well.
\end{abstract}

Keywords: COVID-19, Face Shield, FMEA, Gloves, Mask, Personal Protective Equipment.

\section{Abstrak}

Penyakit virus corona 2019 (COVID-19) yang menular melalui sistem pernafasan manusia memiliki laju infeksi yang sangat tinggi di seluruh dunia, termasuk di Indonesia. Untuk memutus persebaran, Indonesia telah menjalankan sejumlah strategi pembatasan sosial yang berdampak pada penurunan laju pertumbuhan ekonomi secara signifikan dan peningkatan kemiskinan. Demi memenuhi kebutuhan hidup, masyarakat harus tetap bekerja di tengah kekhawatiran terhadap COVID-19. Pekerja informal merupakan sektor pekerja yang paling rentan terhadap penularan karena mereka banyak berinteraksi dengan orang luar dan sulit mematuhi protokol kesehatan. Salah satu pencegahan COVID-19 yang efektif adalah pemakaian Alat Pelindung Diri (APD) seperti masker, face shield, dan sarung tangan. Meskipun efektif, terdapat beberapa potensi risiko APD tersebut yang dapat membahayakan, seperti pemakaian yang salah atau berlebihan, pembersihan yang keliru, pemilihan jenis APD yang salah, dan lain-lain. Oleh karena itu, penelitian ini bertujuan untuk menganalisis risiko rancangan serta penggunaan APD pencegah penularan COVID-19 dan mengkaji rekomendasi pencegahan risiko. Analisis risiko menggunakan metode Failure Mode and Effect Analysis (FMEA) pada produk masker, face shield, dan sarung tangan terhadap konteks pekerja informal secara umum. Terdapat 5 aspek yang dianalisis, yaitu rancangan produk, proses persiapan pemakaian, proses pemakaian, proses penyimpanan, dan proses pembuangan. Berdasarkan hasil analisis, didapatkan total sebanyak 10 risiko masker, 15 risiko face shield, dan 11 risiko sarung tangan yang perlu diperhatikan oleh pekerja informal maupun perancang dan produsen APD.

Kata kunci: Alat Pelindung Diri, COVID-19, Face Shield, FMEA, Masker, Sarung Tangan 


\section{Pendahuluan}

Sejak Desember 2019, dunia digemparkan dengan munculnya COVID-19 yang merupakan penyakit pernafasan akut disebabkan oleh virus corona yang bernama severe acute respiratory syndrome coronavirus 2 atau disingkat SARSCoV-2 (Gorbalenya et al., 2020). Hingga 17 Juni 2020, World Health Organization (WHO) mencatat bahwa terdapat 8.061 .550 orang terinfeksi COVID-19 dan 440.290 orang meninggal dunia (WHO, 2020a). Meskipun Case Fatality Rate (CFR) COVID-19 hanya sekitar $5,46 \%$, penyakit ini sangat berbahaya karena persebaran yang sangat cepat hingga menginfeksi 216 negara (Worldometer, 2020). Selain itu, gejala penyakit ini cukup mengganggu seperti demam, batuk kering, sesak nafas, sakit dada, sakit kepala, diare, dan gejala minor lainnya (Harapan et al., 2020).

Untuk mencegah persebaran yang tidak terkendali, maka WHO menetapkan COVID-19 sebagai pandemi pada 11 Maret 2020 (WHO, 2020b) untuk meningkatkan kewaspadaan akan penyakit ini. Status pandemi ini menjadi perhatian bagi dunia untuk melakukan berbagai upaya pencegahan persebaran COVID-19. Kemampuan virus ini untuk melakukan transmisi antar manusia membuat penyebarannya sulit dikendalikan (Shereen et al., 2020). Secara umum, COVID-19 dapat menular melalui perpindahan cairan tubuh seperti saat batuk atau bersin ketika manusia melakukan kontak jarak dekat. Maka, terdapat beberapa strategi yang umum dilakukan untuk mencegah kontak jarak dekat tersebut, seperti strategi social distancing, lockdown wilayah, rapid diagnostic testing, dan lain-lain.

Sejak 2 Maret 2020, Indonesia termasuk dalam daftar negara yang telah memiliki kasus terinfeksi COVID-19. Hingga 17 Juni 2020, tercatat 41.431 orang terinfeksi dan 2.276 orang meninggal dunia akibat COVID-19 di Indonesia (Gugus Tugas COVID-19, 2020a). Dengan CFR sebesar 5,5\% dan pertambahan kasus yang tinggi, Pemerintah Indonesia mengupayakan berbagai strategi untuk memutus persebaran COVID-19. Beberapa strategi pencegahan yang telah dilakukan oleh Pemerintah antara lain pembentukan Gugus Tugas penanganan COVID-19 (Keppres, 2020), percepatan pengujian COVID-19, penyusunan protokol kesehatan (Gugus Tugas COVID-19, 2020b), dan pelaksanaan
Pembatasan Sosial Berskala Besar (PSBB) (Pemerintah RI, 2020). PSBB merupakan peraturan khusus bagi daerah yang memiliki kasus COVID-19 signifikan untuk membatasi berbagai aktivitas sosial yang minimal meliputi peliburan sekolah dan tempat kerja, pembatasan kegiatan agama, dan pembatasan kegiatan di fasilitas umum (Pemerintah RI, 2020). Meskipun PSBB dianggap efektif menekan persebaran COVID-19, strategi ini memberikan dampak negatif terhadap perekonomian, seperti lumpuhnya aktivitas ekonomi, banyak pekerja dirumahkan maupun dipecat, aktivitas logistik yang terhambat, dan lain-lain. Upaya pencegahan COVID-19 yang masif berdampak pada buruknya pertumbuhan ekonomi Indonesia pada triwulan 1 yang hanya sebesar 2,97\% dari target sekitar 5\% (Badan Pusat Statistik, 2020).

Berdasarkan fenomena tersebut, Pemerintah Indonesia berupaya memberi izin aktivitas perekonomian agar dapat kembali normal (Kemenkes, 2020a, 2020b). Meskipun khawatir, masyarakat harus tetap menjalankan pekerjaannya untuk dapat bertahan hidup. Maka dari itu, diperlukan perlindungan ekstra bagi para pekerja yang harus tetap bekerja.

Salah satu cara melindungi diri dari penularan COVID-19 adalah dengan menggunakan Alat Pelindung Diri (APD). Beberapa jenis APD yang diwajibkan atau disarankan untuk mencegah penularan COVID19 adalah masker (mask), pelindung wajah (face shield), dan sarung tangan (gloves). APD tersebut bertujuan untuk mencegah paparan virus ke dalam tubuh ataupun menularkan virus ke orang lain.

Meskipun seluruh APD tersebut bermanfaat dalam mencegah penularan, APD dapat memiliki risiko yang mengancam keselamatan pekerja selama penggunaan. Berdasarkan penelitian pendahuluan, terdapat beberapa fenomena terkait risiko APD, seperti desain tidak ergonomis, pemakaian berlebihan menimbulkan sakit di beberapa bagian tubuh, penyimpanan dan pembuangan yang membahayakan, dan lainnya. Minimnya kajian dan pemahaman mengenai APD yang baik menimbulkan potensi pekerja tidak sadar akan risiko yang muncul dalam pemakaian APD.

Hingga saat ini, beberapa penelitian terkait risiko pemakaian APD sudah dilakukan, namun belum ada analisis yang spesifik membahas risiko APD terkait pencegah penularan COVID- 
19 dalam rangka mempersiapkan diri untuk menghadapi kebiasaan baru dimana manusia harus tetap beraktivitas di tengah pandemi ini. APD pencegah penularan COVID-19 juga bukan merupakan produk yang umum digunakan untuk bekerja sebelumnya, maka diperlukan analisis dampak risiko terhadap pemakaian APD tersebut jika digunakan pada saat bekerja beserta rekomendasi aksinya agar pekerja tetap terlindungi dari paparan virus.

Oleh karena itu, Penelitian ini bertujuan untuk menganalisis risiko berkaitan dengan desain, persiapan, pemakaian, penyimpanan, dan pembuangan APD pencegah penularan COVID-19. Penelitian ini berfokus pada pekerja informal karena mayoritas pekerja pada sektor ini merupakan pekerja di lapangan yang harus berinteraksi dengan orang banyak, lebih banyak menggunakan aktivitas fisik, dan tidak memiliki perlindungan kesehatan serta lingkungan kerja yang baik. Menurut International Labour Organization (ILO), pekerja informal yang diperkirakan sebanyak $61 \%$ dari total pekerja dunia merupakan pekerja yang paling rentan terhadap risiko keselamatan kerja dan proteksi terhadap COVID-19 (ILO, 2020). Beberapa karakteristik umum pekerja informal di antaranya pekerjaan dominan fisik di lapangan, berpendidikan rendah, ekonomi menengah ke bawah, dan tidak berada di bawah aturan (BPPN, 2009). Contoh pekerja informal yaitu pedagang kaki lima, buruh, tukang reparasi, peternak, dan lain-lain. Contoh pekerja informal terdapat pada Gambar 1.



Gambar 1. Penggunaan APD pada Pekerja Informal - Pedagang Pasar

(Sumber: Merdeka.com)

Pada penelitian ini, analisis risiko dilakukan sesuai dengan karakteristik dan konteks pekerjaan dari para pekerja informal secara umum di Indonesia. Dengan demikian, penelitian ini dapat berkontribusi dalam memaparkan risiko-risiko berkaitan dengan APD dan bagaimana mengatasi risiko tersebut.

\section{Metodologi}

Analisis risiko dilakukan menggunakan metode Failure Mode and Effect Analysis (FMEA) yang merupakan metode terpadu untuk menganalisis dan mengevaluasi risiko potensial dan aktual dari suatu produk atau proses dan aksi potensial untuk mencegah risiko tersebut (Yang \& El-Haik, 2009). Kelebihan FMEA adalah analisis risiko yang lebih mendalam berdasarkan dimensi keparahan, deteksi, dan kejadian yang menghasilkan prioritas risiko, tahapan analisis yang cepat dan mudah, serta adanya rekomendasi aksi untuk menanggulangi tiap potensi risiko yang muncul. Kelemahan dari FMEA adalah penentuan nilai risiko yang membutuhkan justifikasi kualitatif sehingga berpotensi menimbulkan bias. Penelitian ini menggunakan FMEA agar dapat menganalisis risiko APD pencegah penularan COVID-19 secara detail dan cepat serta dapat menghasilkan rekomendasi aksi yang aplikatif dan terstruktur untuk para pekerja informal untuk meminimalkan risiko yang muncul. FMEA juga memudahkan pekerja informal dalam memahami peminimalan risiko mana yang harus lebih diprioritaskan.

FMEA terdiri dari 4 proses utama, yaitu pendefinisian scope produk atau proses yang diamati, identifikasi semua risiko potensial dan aktual yang mungkin terjadi pada sistem, penentuan prioritas risiko, dan perancangan tindakan korektif untuk pencegahan risiko. Pada proses ketiga, terdapat penentuan Risk Priority Number (RPN) untuk menunjukkan risiko yang lebih berbahaya dan pencegahannya lebih urgen untuk dilakukan. Penentuan nilai RPN dapat dilihat pada Tabel 1-3 dengan mengalikan nilai yang didapat dari 3 kriteria berikut (Manuele, 2008):

1. Tingkat keparahan (severity): seberapa parah efek yang ditimbulkan suatu risiko.

2. Tingkat kejadian (occurrence): seberapa besar kemungkinan suatu risiko terjadi.

3. Tingkat deteksi (detection): seberapa mudah mendeteksi terjadinya suatu risiko.

Pada penelitian ini, penentuan nilai RPN tiap risiko dilakukan berdasarkan observasi langsung dan tidak langsung, studi literatur, serta konsensus tim peneliti di bidang keahlian Ergonomi serta Kesehatan dan Keselamatan Kerja (K3) terhadap pengalaman masa lalu dan 
situasi pekerjaan umum pekerja informal di Indonesia saat pandemi berlangsung.

Tabel 1. Kriteria Evaluasi Tingkat Keparahan Risiko

\begin{tabular}{|l|c|}
\hline \multicolumn{1}{|c|}{ Efek } & Nilai \\
\hline Berbahaya: Tanpa Peringatan & 10 \\
\hline Berbahaya: Dengan Peringatan & 9 \\
\hline Sangat Tinggi (Kehilangan fungsi primer) & 8 \\
\hline Tinggi (Kehilangan fungsi sekunder) & 7 \\
\hline Sedang (Efektivitas beberapa fungsi turun) & 6 \\
\hline Rendah (Efektivitas sedikit fungsi turun) & 5 \\
\hline Sangat Rendah (Gangguan ringan) & 4 \\
\hline Minor (Berefek tapi tidak mengganggu) & 3 \\
\hline Sangat Minor (Efek dapat diabaikan) & 2 \\
\hline Tidak Ada Efek Sama Sekali & 1 \\
\hline
\end{tabular}

(Sumber: Manuele, 2008; Yang \& El-Haik, 2009)

Tabel 2. Kriteria Evaluasi Tingkat Kejadian Risiko

\begin{tabular}{|l|c|}
\hline \multicolumn{1}{|c|}{ Probabilitas Kejadian } & Nilai \\
\hline Sangat Tinggi (Sangat sering terjadi) & $9-10$ \\
\hline Tinggi (Sering terjadi) & $7-8$ \\
\hline Sedang (Terjadi sesekali) & $4-6$ \\
\hline Rendah (Jarang terjadi) & $2-3$ \\
\hline Sangat Rendah (Hampir tidak pernah) & 1 \\
\hline
\end{tabular}

(Sumber: Manuele, 2008; Yang \& El-Haik, 2009)

Tabel 3. Kriteria Evaluasi Tingkat Deteksi Risiko

\begin{tabular}{|l|c|}
\hline \multicolumn{1}{|c|}{ Tingkat Deteksi } & Nilai \\
\hline Sama Sekali Tidak Dapat Terdeteksi & 10 \\
\hline Hampir Tidak Dapat Terdeteksi & 9 \\
\hline Kemungkinan Kecil Dapat Terdeteksi & 8 \\
\hline Sangat Rendah (Sangat sulit terdeteksi) & 7 \\
\hline Rendah (Sulit terdeteksi) & 6 \\
\hline Sedang (Peluang terdeteksi/tidak - setara) & 5 \\
\hline Cukup Tinggi (Cukup mudah dideteksi) & 4 \\
\hline Tinggi (Mudah dideteksi) & 3 \\
\hline Sangat Tinggi (Hampir selalu terdeteksi) & 2 \\
\hline Pasti Selalu Terdeteksi dengan Jelas & 1 \\
\hline
\end{tabular}

(Sumber: Manuele, 2008; Yang \& El-Haik, 2009)

Pada penelitian ini, terdapat 3 produk beserta prosesnya yang akan dianalisis berdasarkan konteks penggunaan pekerja informal secara umum di Indonesia, yaitu masker, pelindung wajah, dan sarung tangan. Ketiga produk ini dipilih karena merupakan produk perlindungan utama dari penularan COVID-19 yang mudah diperoleh, relatif terjangkau, dan dianjurkan di Indonesia.

Dalam proses FMEA yang dilakukan, scope sistem yang diamati untuk masing-masing produk terkait dengan 5 hal, yaitu rancangan produk, persiapan pemakaian, pemakaian, penyimpanan, dan pembuangan produk. Analisis kelima hal tersebut dilakukan agar dapat mencakup keseluruhan proses interaksi pengguna dengan produk APD sejak awal mula memilih APD hingga membuang APD tersebut setelah tidak digunakan.

\section{Hasil dan Diskusi}

\section{Masker (Mask)}

Masker merupakan salah satu alat yang berfungsi melindungi pengguna dari partikel berbahaya serta kontaminan yang dapat masuk melalui mulut dan hidung. Fakta bahwa COVID19 menyebar lewat droplets membuat masker menjadi salah satu alat pelindung diri (APD) yang dapat diandalkan karena masker bisa digunakan untuk menahan percikan tersebut menyebar. Dalam bidang kesehatan, masker memiliki fungsi secara umum untuk mencegah kontaminasi virus ataupun penyakit. Pada pemakaian sehari-hari, masker digunakan untuk mengurangi paparan debu dan polusi udara saat berada di luar ruangan.

APD standar yang diwajibkan oleh WHO bagi para pekerja medis yaitu masker medis, sarung tangan, eye protection (goggles atau face shield) dan gown atau baju pelindung tubuh (WHO, 2020d). Bagi pekerja non medis, masker juga menjadi APD yang wajib digunakan untuk melindungi diri selama beraktivitas di luar rumah, khususnya ketika bekerja untuk menyambung kehidupan.

Secara umum masker dapat dibedakan menjadi masker medis atau surgical mask dan masker non medis atau banyak yang menyebutkan sebagai cloth mask atau masker kain dan N95 respirator. Masker medis dan N95 lebih disarankan digunakan oleh petugas kesehatan. Menurut asosiasi Food and Drug Administration (FDA) di Amerika, masker medis atau surgical mask merupakan alat pelindung yang longgar, mudah digunakan, dan untuk penggunaan sekali pakai (FDA, 2020). Masker medis ini memiliki lapisan filter yang berfungsi untuk melindungi pengguna dari partikel, percikan, semprotan yang mungkin saja mengandung bakteri, virus yang dapat ditularkan melalui batuk, bersin, ataupun prosedur medis lainnya. Masker medis lainnya, yaitu N95 merupakan masker yang berfungsi untuk melindungi pengguna dari partikel berbahaya seperti partikel aerosol, droplets, 
dan juga 95\% filtrasi dari partikel airborne yang ada (CDC, 2020a). Pada Gambar 2 terdapat jenis masker yang umum digunakan.



Gambar 2. Jenis Masker

(a) Masker Medis 3 Lapis; (b) Masker Medis N95;

(c) Masker Kain Katun; (d) Masker Kain Scuba (Sumber: www.fda.gov; www.amazon.in; www.halodoc.com; www.lazada.co.id)

Saat terjadi kelangkaan masker medis untuk tenaga medis, masker non medis atau masker kain menjadi alternatif yang mudah didapatkan, ekonomis, dan sustainable karena bisa dipakai beberapa kali dengan pembersihan yang tepat (Esposito et al., 2020). Kementerian Kesehatan mengeluarkan surat edaran baru yang mendukung penggunaan masker non medis berbahan dasar kain. WHO pun turut menyarankan penggunaan masker non medis berbahan dasar kain tiga lapis, yaitu bagian luar yang kedap air (water resistant), bagian tengah yang berfungsi sebagai filter, dan lapisan dalam yang bersifat menyerap air (WHO, 2020c).

Masker kain diharapkan bisa mengurangi potensi perpindahan droplets dari pengguna masker. Center for Disease Control and Prevention (CDC) mengeluarkan petunjuk praktis dalam melindungi diri dan orang lain dari COVID-19, yaitu menutup mulut dan hidung saat berinteraksi dengan orang lain dan mewajibkan penggunaan masker kain jika hendak bepergian. Masker kain tidak disarankan untuk anak berusia di bawah 2 tahun dan pengguna yang memiliki gangguan pernafasan. Selain untuk melindungi diri, penggunaan masker kain merupakan cara untuk melindungi orang lain jika seseorang terinfeksi virus (CDC, 2020a).
WHO mengeluarkan panduan singkat mengenai cara penggunaan masker kain yang efektif sebagai berikut (WHO, 2020c):

1. Mencuci tangan sebelum menyentuh masker.

2. Inspeksi jika masker rusak ataupun kotor.

3. Menggunakan masker tanpa ada celah.

4. Memastikan masker menutup mulut, hidung, dan dagu.

5. Menghindari menyentuh masker dan jika tidak sengaja tersentuh, pengguna mencuci tangan terlebih dahulu.

6. Mencuci tangan sebelum melepaskan masker.

7. Melepaskan masker dari tali pengait yang ada di belakang telinga.

8. Menarik masker dari tali pengait untuk mengeluarkan masker.

9. Menyimpan masker pada plastik dan wadah yang bersih jika masker masih bersih dan layak digunakan kembali.

10.Mencuci masker dengan sabun atau detergen, sebaiknya dengan air panas minimal sekali sehari.

11.Mencuci tangan setelah melepaskan masker.

Kementerian Kesehatan RI mengeluarkan protokol di tempat kerja perkantoran dan industri dalam mendukung keberlangsungan usaha pada situasi pandemi, dengan beberapa petunjuk praktis sebagai berikut (Kemenkes, 2020b):

1. Memastikan tubuh dalam kondisi sehat sebelum berangkat kerja.

2. Menjaga kebersihan tangan dengan sering mencuci tangan dengan sabun dan air mengalir atau hand sanitizer.

3. Menghindari menyentuh area wajah seperti mata, hidung, dan mulut.

4. Tetap menjaga jarak atau physical distancing minimal 1 meter saat berhadapan dengan rekan kerja saat bertugas.

5. Menggunakan pakaian khusus kerja dan mengganti pakaian setelah bekerja.

6. Menggunakan masker saat berangkat dan pulang dari tempat kerja serta selama berada di tempat kerja.

7. Segera mandi dan berganti pakaian sebelum kontak dengan anggota keluarga di rumah.

Meskipun masker terbukti sangat efektif sebagai APD pencegah penularan COVID-19, terdapat beberapa risiko yang perlu 
diperhatikan oleh pekerja informal maupun produsen yang membuatnya agar penggunaan masker tidak menimbulkan masalah. Analisis risiko masker beserta usulan aksi untuk mengatasinya terdapat pada Tabel 4 dan 5.

Tabel 4. Failure Mode and Effect Analysis APD Masker (Rancangan, Persiapan Pemakaian, dan Pemakaian)

\begin{tabular}{|c|c|c|c|c|c|c|c|c|c|c|c|c|}
\hline \multicolumn{13}{|c|}{ FAILURE MODE AND EFFECT ANALYSIS (FMEA) } \\
\hline Process: & \multicolumn{4}{|c|}{$\begin{array}{l}\text { Rancangan dan Pemakaian APD saat bekerja untuk } \\
\text { mencegah penularan COVID-19 }\end{array}$} & \multicolumn{2}{|l|}{ Responsibility: } & \multicolumn{4}{|c|}{ Pusat Studi Ergonomi UNPAR } & Number: & 1 \\
\hline Product: & \multicolumn{4}{|l|}{ Masker / Mask } & \multicolumn{2}{|l|}{ Prepared by: } & \multicolumn{4}{|c|}{ Pusat Studi Ergonomi UNPAR } & Page: & 1 \\
\hline Core team: & \multicolumn{4}{|c|}{$\begin{array}{l}\text { Yansen Theopilus, S.T., M.T } \\
\text { Dr.Thedy Yogasara, S.T., M.Eng.Sc } \\
\text { Dr. Johanna Renny Octavia Hariandja, S.T., M.Sc.,PDEng } \\
\text { Clara Theresia, S.T., M.T }\end{array}$} & \multicolumn{2}{|l|}{ Key Date: } & \multicolumn{4}{|l|}{ 6/6/2020 } & Modified: & - \\
\hline Process Step & Function & Failure Mode & Failure Effect & ڤે & $\begin{array}{c}\text { Potential Failure } \\
\text { Cause }\end{array}$ & 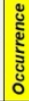 & $\begin{array}{l}\text { Preventive } \\
\text { Action }\end{array}$ & $\begin{array}{l}\text { Detection } \\
\text { Action }\end{array}$ & 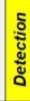 & $a_{0}^{2}$ & Recol & \\
\hline \multirow[t]{3}{*}{$\begin{array}{l}\text { Rancangan } \\
\text { masker non } \\
\text { medis }\end{array}$} & $\begin{array}{l}\text { Memastikan } \\
\text { rancangan } \\
\text { ukuran masker } \\
\text { yang dibuat } \\
\text { sudah efektif }\end{array}$ & \begin{tabular}{|l|} 
Kontaminasi virus \\
COVID-19 jika \\
ukuran masker \\
tidak sesuai \\
(terlalu besar dan \\
longgar atau \\
terlalu sempit)
\end{tabular} & \begin{tabular}{|l|} 
Meningkatkan \\
potensi penularan \\
cOVID-19 dan \\
penggunaan \\
jangka panjang \\
bisa menimbulkan \\
luka di \\
permukaan kulit
\end{tabular} & 7 & $\begin{array}{l}\text { Ukuran masker } \\
\text { yang digunakan } \\
\text { tidak sesuai } \\
\text { dengan } \\
\text { antropometri } \\
\text { pekerja sehingga } \\
\text { bisa terlalu ketat } \\
\text { ataupun longgar }\end{array}$ & 6 & \begin{tabular}{|l|} 
Mencari tahu \\
terlebih dahulu \\
ukuran masker \\
sebelum dibeli \\
atau digunakan \\
agar masker yang \\
dipilih sesuai \\
dengan \\
pengguna
\end{tabular} & $\begin{array}{l}\text { Inspeksi sebelum } \\
\text { memilh } \\
\text { rancangan } \\
\text { masker yang } \\
\text { akan digunakan } \\
\text { saat bekerja }\end{array}$ & 5 & 210 & $\begin{array}{l}\text { Pengguna } \\
\text { rancangan } \\
\text { menyesuai } \\
\text { masing-ma } \\
\text { digunakan } \\
\text { sempit) dar } \\
\text { hidung dan } \\
\text { sempurna }\end{array}$ & \\
\hline & \multirow[t]{2}{*}{\begin{tabular}{|l|} 
Memastikan \\
material yang \\
digunakan untuk \\
pembuatan \\
masker sudah \\
efektif (material \\
berbahan kain \\
katun, scuba dil) \\
\end{tabular}} & \multirow[t]{2}{*}{\begin{tabular}{|l|} 
Kesulitan untuk \\
bernafas ketika \\
bekerja \\
menggunakan \\
masker serta \\
material yang \\
tidak baik akan \\
menurunkan \\
kemampuan filter \\
masker yang \\
digunakan
\end{tabular}} & \begin{tabular}{|l|} 
Meningkatkan \\
potensi penularan \\
COVID-19 jika \\
masker tidak \\
memilki material \\
filter yang tepat
\end{tabular} & 8 & $\begin{array}{l}\text { Material yang } \\
\text { kurang sesuai } \\
\text { untuk rancangan } \\
\text { masker }\end{array}$ & 6 & \begin{tabular}{|l|} 
Mencari tahu \\
material masker \\
sebelum membeli \\
masker dan \\
menyesuaikan \\
dengan aktivitas \\
pengguna
\end{tabular} & $\begin{array}{l}\text { Inspeksi sebelum } \\
\text { memilih material } \\
\text { masker yang } \\
\text { akan digunakan } \\
\text { saat bekerja }\end{array}$ & 7 & 336 & \multirow{2}{*}{\multicolumn{2}{|c|}{$\begin{array}{l}\text { Pengguna sebaiknya memilih } \\
\text { rancangan masker yang digunakan } \\
\text { sebaiknya berbahan dasar kain } \\
\text { katun dengan } 3 \text { lapisan filter: inner } \\
\text { layer, outer layer dan middle layer } \\
\text { (WHO, 2020c) } \\
\text { Konfigurasi tiga lapisan yang } \\
\text { dianjurkan: } \\
\text { Lap. dalam: Bahan menyerap air } \\
\text { (Katun, scuba, dll) } \\
\text { Lap, tengah: Bahan penyaring } \\
\text { (Tissue, dil) } \\
\text { Lap. luar: Bahan tahan air (Taslan, } \\
\text { dil) } \\
\text { Pemilihan bahan bisa disesuaikan } \\
\text { dengan ketersediaan }\end{array}$}} \\
\hline & & & \begin{tabular}{|l|} 
Meningkatkan \\
potensi gangguan \\
pernafasan saat \\
beraktivitas
\end{tabular} & 8 & \begin{tabular}{|l} 
Material yang \\
digunakan terlalu \\
tebal dan tidak \\
memiliki layer dari \\
material yang \\
tepat
\end{tabular} & 6 & $\begin{array}{l}\text { Mencari tahu } \\
\text { material masker } \\
\text { yang dipilih } \\
\text { sebaiknya } \\
\text { berbahan kain } \\
\text { katun yang } \\
\text { nyaman }\end{array}$ & $\begin{array}{l}\text { Inspeksi sebelum } \\
\text { memilih material } \\
\text { masker yang } \\
\text { akan digunakan } \\
\text { saat bekerja }\end{array}$ & 7 & 336 & & \\
\hline \multirow[t]{2}{*}{$\begin{array}{l}\text { Persiapan } \\
\text { pemakaian } \\
\text { masker non } \\
\text { medis } \\
\text { (material } \\
\text { berbahan kain } \\
\text { katun, scuba } \\
\text { dil) }\end{array}$} & \multirow[t]{2}{*}{$\begin{array}{l}\text { Memastikan } \\
\text { pekerja } \\
\text { menggunakan } \\
\text { masker dengan } \\
\text { tepat }\end{array}$} & \begin{tabular}{|l} 
Kontaminasi virus \\
melalui tangan \\
yang kotor \\
sebelum \\
menggunakan \\
masker
\end{tabular} & $\begin{array}{l}\text { Meningkatkan } \\
\text { potensi penularan } \\
\text { COVID-19 }\end{array}$ & 8 & $\begin{array}{l}\begin{array}{l}\text { Tidak mencuci } \\
\text { tangan sebelum } \\
\text { menggunakan } \\
\text { masker }\end{array} \\
\end{array}$ & 7 & \begin{tabular}{|l|} 
Mengecek \\
kebersihan \\
tangan sebelum \\
menggunakan \\
masker
\end{tabular} & $\begin{array}{l}\text { Inspeksi sebelum } \\
\text { bekerja: } \\
\text { Mengecek } \\
\text { kebersihan } \\
\text { sebelum } \\
\text { menggunakan } \\
\text { masker }\end{array}$ & 5 & 280 & \multicolumn{2}{|c|}{$\begin{array}{l}\text { Pengguna diwajibkan untuk } \\
\text { mencuci tangan selama 20-30 detik } \\
\text { (sabun berbahan alkohol) dan 40- } \\
60 \text { detik dengan sabun dan air } \\
\text { sebelum menyentuh masker (WHO, } \\
\text { 2020c) }\end{array}$} \\
\hline & & \begin{tabular}{|l|} 
Hidung dan mulut \\
tidak tertutup \\
rapat saat \\
menggunakan \\
masker
\end{tabular} & \begin{tabular}{|l|} 
Partikel \\
kontaminan \\
ataupun virus \\
dapat dengan \\
mudah masuk ke \\
tubuh
\end{tabular} & 8 & $\begin{array}{l}- \text { - Pengguna } \\
\text { sengaja } \\
\text { membuka } \\
\text { sebagian masker } \\
\text { karena merasa } \\
\text { tidak nyaman } \\
\text { - Pemasangan } \\
\text { masker tidak } \\
\text { sempurna } \\
\text { - Ukuran masker } \\
\text { tidak sesuai }\end{array}$ & 8 & \begin{tabular}{|l|} 
Mengecek dan \\
memastikan \\
hidung dan mulut \\
tertuttup dengan \\
baik saat \\
memakai masker \\
\end{tabular} & $\begin{array}{l}\text { Inspeksi sebelum } \\
\text { bekerja: } \\
\text { Memastikan mulut } \\
\text { dan hidung } \\
\text { tertutup rapat } \\
\text { saat } \\
\text { menggunakan } \\
\text { masker }\end{array}$ & 5 & 320 & \multicolumn{2}{|c|}{$\begin{array}{l}\text { - Pengguna memastikan bahwa } \\
\text { seluruh hidung dan mulut tertutup } \\
\text { saat memakai masker (WHO, } \\
2020 c \text { ) } \\
\text { - Pengguna dapat memahami } \\
\text { edukasi mengenai pemakaian } \\
\text { masker tanpa hidung dan mulut } \\
\text { yang tertutup rapat sama dengan } \\
\text { sia-sia } \\
\text { - Pemilihan ukuran masker yang } \\
\text { tepat dan nyaman }\end{array}$} \\
\hline \multirow[t]{4}{*}{$\begin{array}{l}\text { Pemakaian } \\
\text { masker }\end{array}$} & \multirow[t]{4}{*}{$\begin{array}{l}\text { Melindungi } \\
\text { pekerja dari } \\
\text { bahaya penularan } \\
\text { COVID } 19\end{array}$} & \multirow[t]{2}{*}{$\begin{array}{l}\text { Kontaminasi oleh } \\
\text { diri sendiri melalui } \\
\text { sentuhan dan } \\
\text { penggunaan } \\
\text { kembali setelah } \\
\text { melepas masker }\end{array}$} & \begin{tabular}{|l|} 
Meningkatnya \\
i potensi \\
penyebaran \\
kontaminan jika \\
menyentuh \\
masker dengan \\
tangan yang tidak \\
bersih
\end{tabular} & 8 & $\begin{array}{l}\text { Menyentuh } \\
\text { masker saat } \\
\text { bekerja }\end{array}$ & 7 & \begin{tabular}{|l|} 
Mendisiplinkan \\
diri dan \\
memastikan agar \\
tidak menyentuh \\
masker saat \\
bekerja
\end{tabular} & $\begin{array}{l}\text { Inspeksi saat } \\
\text { bekerja agar } \\
\text { jangan } \\
\text { menyentuh } \\
\text { masker }\end{array}$ & 5 & 280 & \multicolumn{2}{|c|}{$\begin{array}{l}\text { - Sebaiknya pengguna tidak } \\
\text { menyentuh masker saat bekerja } \\
\text { (WHO, 2020c) dan pedoman } \\
\text { Kemenkes Rl untuk tidak } \\
\text { menyentuh masker saat bekerja } \\
\text { dan berada di tempat umum } \\
\text { (Kemenkes RI, 2020b) } \\
\text { - Pastikan tidak menyentuh bagian } \\
\text { tengah dari masker saat } \\
\text { beraktivitas dan jika ingin } \\
\text { melepaskan masker sebaiknya dari } \\
\text { bagian tali saja (WHO, 2020c) }\end{array}$} \\
\hline & & & \begin{tabular}{|l|} 
Terkena \\
penularan COVID- \\
19 dari droplets, \\
sentuhan dan \\
media \\
penyebaran \\
lainnya
\end{tabular} & 8 & $\begin{array}{l}\text { Melepaskan } \\
\text { masker di tempat } \\
\text { umum }\end{array}$ & 9 & \begin{tabular}{|l|} 
Memastikan \\
untuk disiplin dan \\
jaga jarak minimal \\
1 meter serta \\
tidak melepaskan \\
masker di tempat \\
umum
\end{tabular} & \begin{tabular}{|l|} 
Inspeksi saat \\
bekerja agar tidak \\
melepaskan \\
masker saat \\
berada di \\
keraiaman
\end{tabular} & 8 & 576 & \multicolumn{2}{|c|}{\begin{tabular}{|l|} 
Sebaiknya pengguna tidak \\
melepaskan masker saat berada di \\
tempat umum dan memastikan \\
physical distancing minimal 1 \\
meter (WHO, 2020c)
\end{tabular}} \\
\hline & & $\begin{array}{l}\begin{array}{l}\text { Masker tidak } \\
\text { dapat berfungsi } \\
\text { dengan baik }\end{array} \\
\end{array}$ & \begin{tabular}{|l|} 
Filter masker \\
tidak berfungsi \\
secara maksimal \\
sehingga \\
meningkatkan \\
risiko penularan \\
COVID 19
\end{tabular} & 8 & $\begin{array}{l}\text { Menggunakan } \\
\text { masker lebih dari } \\
4 \text { jam }\end{array}$ & 9 & \begin{tabular}{|l|} 
Mengecek durasi \\
pemakaian \\
masker dan jika \\
masker basah \\
ataupun robek \\
sebaiknya \\
langsung diganti \\
\end{tabular} & $\begin{array}{l}\text { Inspeksi saat } \\
\text { bekerja agar tidak } \\
\text { menggunakan } \\
\text { masker jika sudah } \\
\text { lebih dari } 4 \text { jam }\end{array}$ & 5 & 360 & \multicolumn{2}{|c|}{$\begin{array}{l}\text { - Mengganti masker yang } \\
\text { digunakan diatas } 4 \text { jam (Shakya et } \\
\text { al., 2016) } \\
\text { - Sebaiknya pekerja memiliki 2-3 } \\
\text { buah masker cadangan per hari } \\
\text { yang dibawa saat bekerja } \\
\text { - Sebaiknya pekerja memiliki total } \\
\text { sebanyak 4-6 buah masker }\end{array}$} \\
\hline & & $\begin{array}{l}\text { Gangguan } \\
\text { pernafasan saat } \\
\text { menggunakan } \\
\text { masker untuk } \\
\text { aktivitas berat }\end{array}$ & $\begin{array}{l}\text { Masker membuat } \\
\text { pengguna merasa } \\
\text { tidak nyaman dan } \\
\text { sesak nafas }\end{array}$ & 8 & $\begin{array}{l}\text { Menggunakan } \\
\text { masker saat } \\
\text { melakukan } \\
\text { aktivitas } \\
\text { pekerjaan yang } \\
\text { berat }\end{array}$ & 7 & $\begin{array}{l}\text { Mengecek dan } \\
\text { memastikan } \\
\text { masker yang } \\
\text { digunakan } \\
\text { nyaman saat } \\
\text { beraktivitas }\end{array}$ & $\begin{array}{l}\text { Inspeksi saat } \\
\text { bekerja apabila } \\
\text { merasa tidak } \\
\text { nyaman ataupun } \\
\text { sulit bernafas }\end{array}$ & 7 & 392 & \multicolumn{2}{|c|}{$\begin{array}{l}\text { - Hindari penggunaan masker kain } \\
\text { untuk aktivitas pekerjaan yang } \\
\text { berat. } \\
\text { - Misalnya saja ada himbauan } \\
\text { WHO agar tidak menggunakan } \\
\text { masker kain selama berolahraga } \\
\text { karena masker yang basah akan } \\
\text { berpotensi menimbulkan } \\
\text { kontaminan dan virus muncul } \\
\text { (WHO, 2020c). } \\
\text { - Sebaiknya saat beraktivitas berat } \\
\text { memilih jenis masker yang sesuai } \\
\text { dan tidak menyulitkan saat } \\
\text { bernafas }\end{array}$} \\
\hline
\end{tabular}


Tabel 5. Failure Mode and Effect Analysis APD Masker (Penyimpanan, Pembuangan)



Pada FMEA produk masker, terdapat 10 potensi risiko yang muncul dalam penggunaan masker sebagai APD. Nilai prioritas risiko tertinggi yang dianalisis terletak pada proses pemakaian masker $(\mathrm{RPN}=576)$. Potensi risiko yang paling tinggi terjadi saat pekerja memakai masker yakni pada proses melepaskan masker di tempat umum. Risiko ini memperbesar potensi penularan virus dan kontaminan berbahaya. Dampak risiko yang muncul adalah pengguna bisa terkena penularan COVID-19 lewat droplets, sentuhan, dan media lainnya. Hingga saat ini, WHO telah mengeluarkan protokol kesehatan yang menganjurkan pengguna masker kain agar tidak melepaskan masker saat berada di tempat umum dan tetap menjaga jarak atau physical distancing minimal 1 meter saat berinteraksi dengan orang lain (WHO, 2020c). Meskipun adanya edaran dan himbauan tersebut, tingkat kesadaran dan kedisiplinan pengguna masih sangat rendah sehingga risiko yang muncul saat melepaskan masker di tempat umum masih tergolong sangat tinggi atau sangat sering terjadi dengan nilai occurrence di angka 9. Nilai skor severity atau dampak risiko berada pada skor 8 yang menyatakan bahwa dampak risiko yang terjadi akibat kelalaian membuka masker saat digunakan ini cukup tinggi. Potensi risiko dapat diminimalkan jika adanya deteksi dini terhadap risiko yang muncul, tetapi pada proses tersebut nilai skor detection berada di angka 8 yang menunjukkan deteksi aktivitas tersebut sangat rendah (Manuele, 2008).

Nilai prioritas risiko yang cukup tinggi juga terdapat pada proses membersihkan masker yang layak pakai untuk digunakan kembali $(\mathrm{RPN}=512)$. Pada proses membersihkan masker, potensi risiko yang sering terjadi adalah kelalaian dengan menggunakan masker kembali tanpa dibersihkan terlebih dahulu (occurrence $=8$ dengan kategori sangat sering terjadi). Proses pembersihan masker pun tidak bisa diabaikan mengingat potensi risiko masih adanya kontaminan yang menempel pada masker yang belum dibersihkan dengan baik (severity score $=8$ dengan kategori bahaya sangat tinggi). Proses pencegahan atau deteksi yang bisa dilakukan pengguna memiliki skor 8 yang artinya tingkat deteksi atau kelalaian tersebut sangat rendah sekali karena kedisiplinan pengguna masker pemakaian berulang masih cukup rendah untuk menjaga kebersihan masker sebelum digunakan kembali. WHO telah mengeluarkan protokol untuk membersihkan masker pemakaian berulang 
bahwa sebaiknya masker dicuci menggunakan detergen dan air panas serta mengeringkan masker yang telah dicuci dengan baik (WHO, 2020c).

Pada proses pembuangan masker yang sudah tidak layak pakai juga memiliki skor RPN yang cukup tinggi, yaitu 448. Proses pembuangan masker yang sudah tidak layak pakai cenderung sering diabaikan. Pengguna merasa masker yang dipakai masih cukup layak meskipun sudah longgar atau robek. Potensi risiko pada proses pembuangan masker, yaitu masker tidak dibuang secara terpisah dengan sampah lainnya (occurrence $=7$ dengan kategori sering terjadi). Dampak yang muncul dari proses pembuangan masker yang tidak tepat adalah menyebarnya kontaminan berbahaya dari masker yang telah dipakai (severity= 8 dengan kategori bahaya sangat tinggi). Deteksi dini yang bisa dilakukan adalah dengan melakukan pengecekan kembali sebelum membuang masker agar terpisah dari bagian lain dan tidak bercampur dengan sampah lainnya saat dibuang di tong sampah (skor detection= 8, deteksi sangat rendah sekali).

\section{Pelindung Wajah (Face Shield)}

Face shield adalah tameng transparan yang menutupi wajah dan mencegah droplet yang mengandung virus memasuki mata, hidung, dan mulut (Ravenscroft, 2020). Face shield merupakan APD yang banyak digunakan oleh pekerja medis. Namun dengan merebaknya wabah COVID-19, saat ini face shield banyak pula digunakan oleh masyarakat umum. Hal ini disebabkan fungsinya yang cukup efektif melindungi dari risiko terinfeksi COVID-19. APD ini juga banyak tersedia di pasaran dan harganya terjangkau, bahkan dapat dibuat sendiri dengan peralatan sederhana.

Suatu studi menggunakan simulator batuk yang menyemburkan aerosol yang mengandung virus influenza (Lindsley et al., 2014), menunjukkan bahwa penggunaan face shield dapat menahan paparan virus sebesar 68\%-96\% pada jarak $46 \mathrm{~cm}$ dari sumber batuk dan sesaat setelah batuk, bergantung pada diameter droplet $(3,4-8,5 \mu \mathrm{m})$. Walaupun demikian, face shield sangat dianjurkan untuk tidak digunakan sebagai satu-satunya APD utama, tetapi digunakan bersamaan dengan APD lainnya, seperti masker dan safety goggles (Lindsley et al., 2014; Roberge, 2016), karena cairan mikro yang mungkin masuk ke wajah melalui sisi face shield.

Cukup banyak jenis face shield yang tersedia, mulai dari tipe profesional untuk pekerja medis hingga tipe buatan sendiri (doit-yourself). Pada penelitian ini, analisis face shield difokuskan pada jenis yang dapat digunakan oleh pekerja umum, khususnya pekerja informal (blue-collar worker), dan memiliki harga yang relatif murah. Secara garis besar, face shield tersebut dapat diklasifikasikan menjadi dua kategori (Karyaone, 2020):

\section{Standard face shield}

Face shield tipe ini memiliki struktur sederhana, yaitu bagian rangka (frame), tameng transparan (visor), dan pengikat (Roberge, 2016). Bagian rangka biasanya terbuat dari plastik ringan dan berfungsi sebagai tempat dipasangnya visor dan dudukan ke kepala pengguna. Bagian frame yang bersentuhan dengan kepala pengguna biasanya dilapisi bantalan busa (foam cushion) agar lebih nyaman digunakan. Frame ini disambung dengan pengikat berupa material elastis atau tali velcro sebagai pengencang ke kepala. Pada tipe tertentu, bagian frame ini dapat diganti dengan bentuk kacamata. Bagian visor secara umum terbuat dari plastik transparan seperti polycarbonate, propionate, acetate, PVC, dan PETG dengan berbagai variasi ketebalan. Bagian visor dipasang pada rangka menggunakan baut atau kancing pin, dan pada beberapa model, bagian visor ini dapat dinaikkan dan diturunkan tanpa perlu melepas frame dari kepala. Contoh standard face shield terdapat pada Gambar 3.

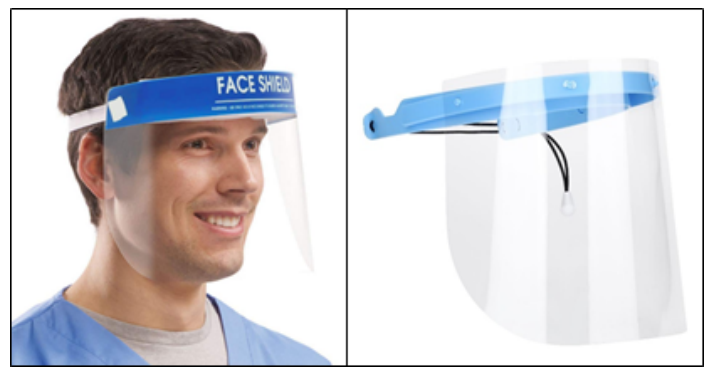

Gambar 3. Contoh Standard Face Shield (Sumber: www.coccare.com; www.ufuncase.com) 


\section{Face shield with cap/hat}

Face shield with cap/hat pada dasarnya mirip dengan standard face shield, hanya saja digunakan topi sebagai frame. Dengan demikian, bagian atas kepala pengguna dapat lebih terlindungi, sekaligus mencegah droplet masuk melalui bagian atas wajah. Face shield tipe ini juga dianggap lebih nyaman dikenakan karena ukuran topi telah disesuaikan dengan ukuran kepala pengguna. Beberapa contoh face shield with cap/hat ditunjukkan pada Gambar 4.



Gambar 4. Contoh Face Shield with Cap/Hat (Sumber: www.mollyssarasota.com; www.wish.com)

Face shield memiliki beberapa kelebihan sebagai berikut: (Perencevich et al., 2020; Roberge, 2016; Ravenscroft, 2020):

1. Melindungi seluruh bagian wajah (mata, hidung, dan mulut) dari paparan infectious droplet.

2. Cenderung lebih nyaman digunakan karena tidak melekat rapat seperti masker dan tidak terasa terlalu panas pada wajah.

3. Memiliki durability yang cukup tinggi dan dapat dibersihkan (disinfected) dengan mudah untuk dipakai ulang.

4. Mudah dipasang dan dilepaskan.

5. Tidak mengganggu pernafasan.

6. Memiliki harga yang relatif terjangkau dan ketersediaan cukup banyak di pasaran.

7. Tidak mengganggu pengguna dalam berbicara.

8. Dapat digunakan bersamaan dengan APD lain seperti kacamata dan masker.

9. Mencegah pengguna untuk menyentuh wajahnya.

10. Tidak menghalangi komunikasi nonverbal melalui ekspresi wajah, serta tidak menghambat komunikasi melalui pembacaan gerak bibir bagi tuna rungu.
11. Pemakaian face shield dapat memperpanjang usia pemakaian masker saat dipakai bersamaan.

Beberapa kelemahan face shield adalah (Roberge, 2016):

1. Dapat menimbulkan kesilauan (glare).

2. Dapat timbul kabut pada visor akibat uap nafas, sehingga mengganggu pandangan.

3. Dapat menimbulkan distorsi penglihatan.

4. Berukuran cukup besar.

5. Dibanding masker, terdapat risiko droplet masuk melalui sisi face shield yang terbuka, jika lebar visor kurang. Hal ini terkait face shield yang memiliki peripheral fit (kerapatan bagian sisi) lebih buruk dibanding masker.

Proses penggunaan face shield adalah sebagai berikut:

1. Face shield yang hendak dipakai harus dipastikan bersih.

2. Pengguna mencuci tangannya dan memegang face shield hanya pada bagian frame atau tali pengikat untuk mencegah bagian visor terkontaminasi.

3. Face shield dipasangkan dengan posisi yang tepat dan bagian bantalan busa harus menempel rapat pada bagian dahi. Bagian pengikat harus memiliki ukuran dan daya ikat yang tepat sehingga tidak longgar atau tidak terlalu kencang. Jika berbentuk topi, ukuran topi harus tepat serta nyaman.

4. Saat digunakan, jarak visor harus diatur sehingga tidak terlalu jauh dari wajah sehingga membuka celah pada bagian bawah dan sisi wajah, namun juga tidak terlalu dekat sehingga menyebabkan kesulitan bernafas atau timbul uap embusan nafas pada visor.

5. Selama penggunaan, sentuhan tangan pada bagian visor harus diminimalkan untuk mengurangi risiko terkontaminasi virus dari tangan pengguna.

6. Untuk melepaskan visor, pengguna perlu mencuci tangan terlebih dahulu lalu melepaskan face shield dengan memegang bagian topi atau pengikat dengan tangan.

7. Sebelum disimpan, seluruh bagian face shield harus dicuci bersih dengan sabun atau detergen. Setelah dikeringkan, face shield disimpan di tempat yang bersih 
untuk dapat dipergunakan kembali kemudian.

8. Untuk pembuangan, sebaiknya face shield dicuci terlebih dahulu dan bagian visor dapat dipotong-potong untuk mencegah face shield digunakan kembali oleh pihak lain dan menjadi media potensial penularan virus.

Sebelum adanya pandemi COVID-19, face shield bukanlah produk yang umum untuk digunakan oleh pekerja atau masyarakat. Maka dari itu, ketika saat ini face shield menjadi salah satu APD pencegah penularan virus yang efektif, diperlukan analisis terhadap risiko-risiko yang mungkin muncul dalam rancangan atau pemakaian face shield. Analisis risiko face shield serta usulan aksi untuk mengatasinya terdapat pada Tabel 6 dan 7.

Berdasarkan analisis FMEA terhadap produk face shield, terdapat 15 potensi risiko yang perlu diperhatikan agar pengguna terhindar dari bahaya dalam penggunaannya. Tiga risiko face shield yang paling prioritas untuk diperhatikan adalah face shield tidak dibersihkan atau dibersihkan dengan cara yang salah setelah digunakan (RPN= 560), bagian visor pada face shield memiliki dimensi yang tidak sesuai (RPN=480), dan face shield mengontaminasi pengguna saat digunakan (RPN= 392).

Face shield terbukti efektif untuk menahan droplets dari orang lain ke area wajah pengguna. Namun, perlu diingat pula bahwa droplets yang tertahan tersebut tertinggal pada permukaan visor pada face shield, sehingga perlu pembersihan yang baik setelah digunakan. Jika tidak dibersihkan dengan baik, maka sisa kotoran atau bahkan paparan virus pada visor tersebut dapat mengontaminasi area sekitar bahkan tubuh pengguna. Sering kali, pekerja tidak membersihkan peralatan kerjanya dengan baik, misalnya: pengemudi tidak membersihkan helmnya setiap hari, pekerja konstruksi tidak mencuci sarung tangannya setiap hari, atau pedagang kaki lima tidak mencuci gerobaknya setiap hari. Maka dari itu, diperlukan kesadaran dan pemahaman yang tinggi akan pentingnya pembersihan face shield sebagai alat perlindungan diri, agar usaha melawan penularan COVID-19 tidak sia-sia.
Bagian face shield yang berperan vital dalam menahan droplets adalah visor. Visor yang baik perlu memiliki ketebalan minimal 0,5 mm serta menutupi secara vertikal (bagian dahi hingga dagu) dan horizontal (telinga hingga telinga) dengan sempurna tanpa celah. Pemakaian face shield akan menjadi percuma jika bagian visor dibuat dengan tidak benar dan area wajah tidak terlindungi dengan baik. Maka dari itu, para pekerja harus lebih memperhatikan model visor pada face shield yang akan dibeli, dan sebisa mungkin dapat mencobanya dahulu agar memastikan ukuran visor dapat menutupi wajahnya dengan sempurna.

Ketika digunakan untuk bekerja seharihari, face shield sebaiknya tidak disentuh oleh tangan sendiri maupun orang lain karena droplets pada permukaan visor dapat mengontaminasi tangan seseorang. Hal ini sangat penting mengingat manusia memiliki probabilitas menyentuh wajahnya sendiri hingga 16x dalam sejam (Citroner, 2020). Jika tangan menyentuh wajah setelah menyentuh visor bagian luar, maka akan sangat berbahaya bagi pengguna. Ketika memakai atau melepaskan face shield, pengguna juga perlu berhati-hati untuk menghindari pemegangan pada bagian luar visor semaksimal mungkin.

Pemilihan produk face shield juga sangat penting untuk dilakukan, khususnya karena face shield yang beredar di pasaran saat ini memiliki variasi yang cukup tinggi dalam hal kualitas dan juga harga. Hendaknya pengguna dapat memilih face shield dengan visor yang menutupi wajah dengan sempurna dan ketebalan yang sesuai. Face shield yang murah sering kali memiliki visor yang terlalu tipis sehingga membuat perlindungan tidak maksimal dan face shield menjadi cepat rusak. Dengan demikian, tujuan seseorang membeli face shield yang murah agar lebih irit tidak akan tercapai karena pada kenyataannya harus berkali-kali membeli. Mekanisme pemasangan face shield pada wajah juga perlu disesuaikan dengan jenis pekerjaan. Untuk pekerjaan yang memiliki mobilitas tinggi seperti pekerja konstruksi atau pedagang kaki lima, sebaiknya menggunakan face shield dengan mekanisme pengencangan yang maksimal agar tidak mudah terlepas saat bekerja. 
Tabel 6. Failure Mode and Effect Analysis APD Face Shield (Rancangan dan Persiapan Pemakaian)

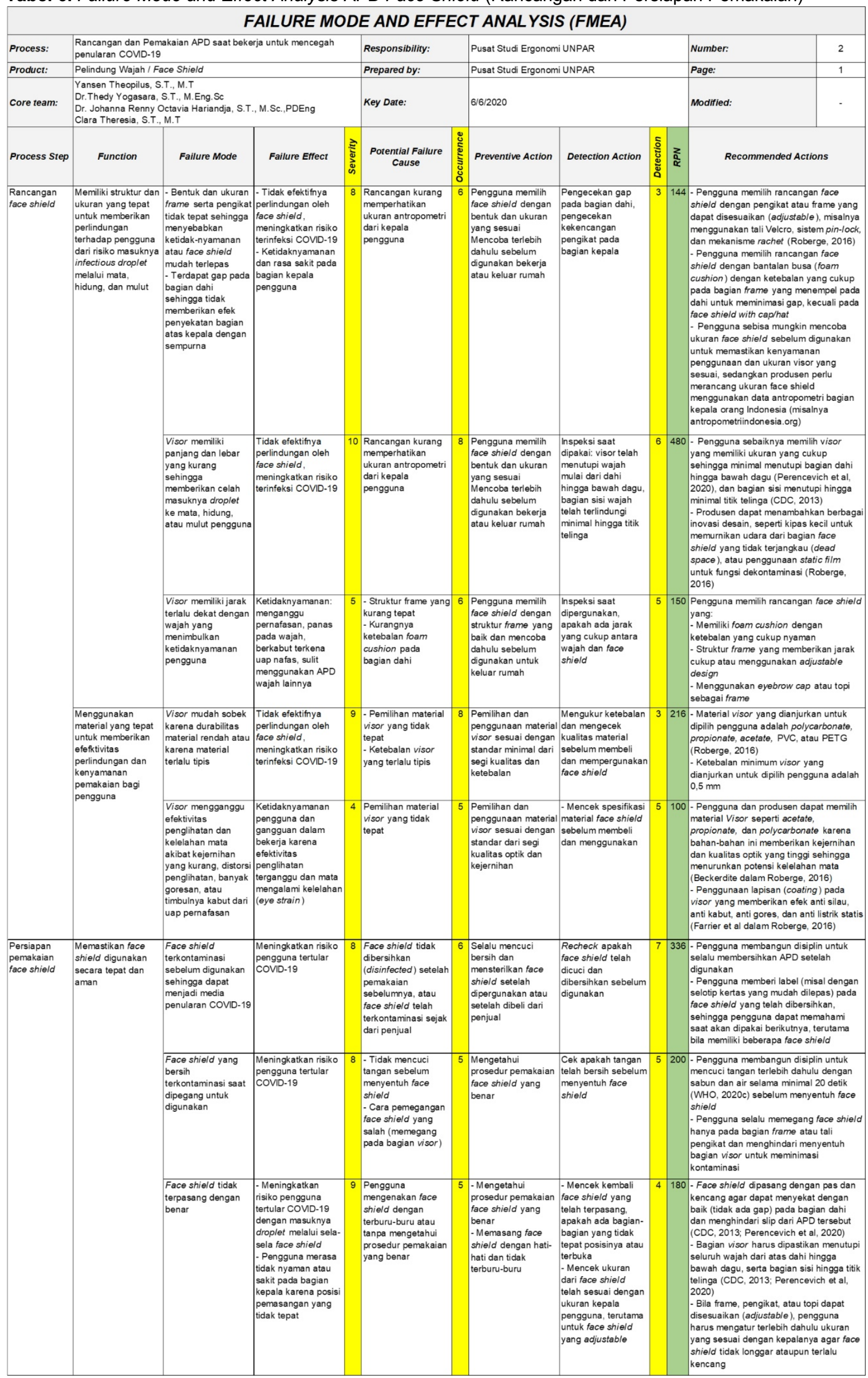


DOI: https://doi.org/10.26593/irsi.v9i2.4002.115-134

Tabel 7. Failure Mode and Effect Analysis APD Face Shield (Pemakaian, Penyimpanan, Pembuangan)

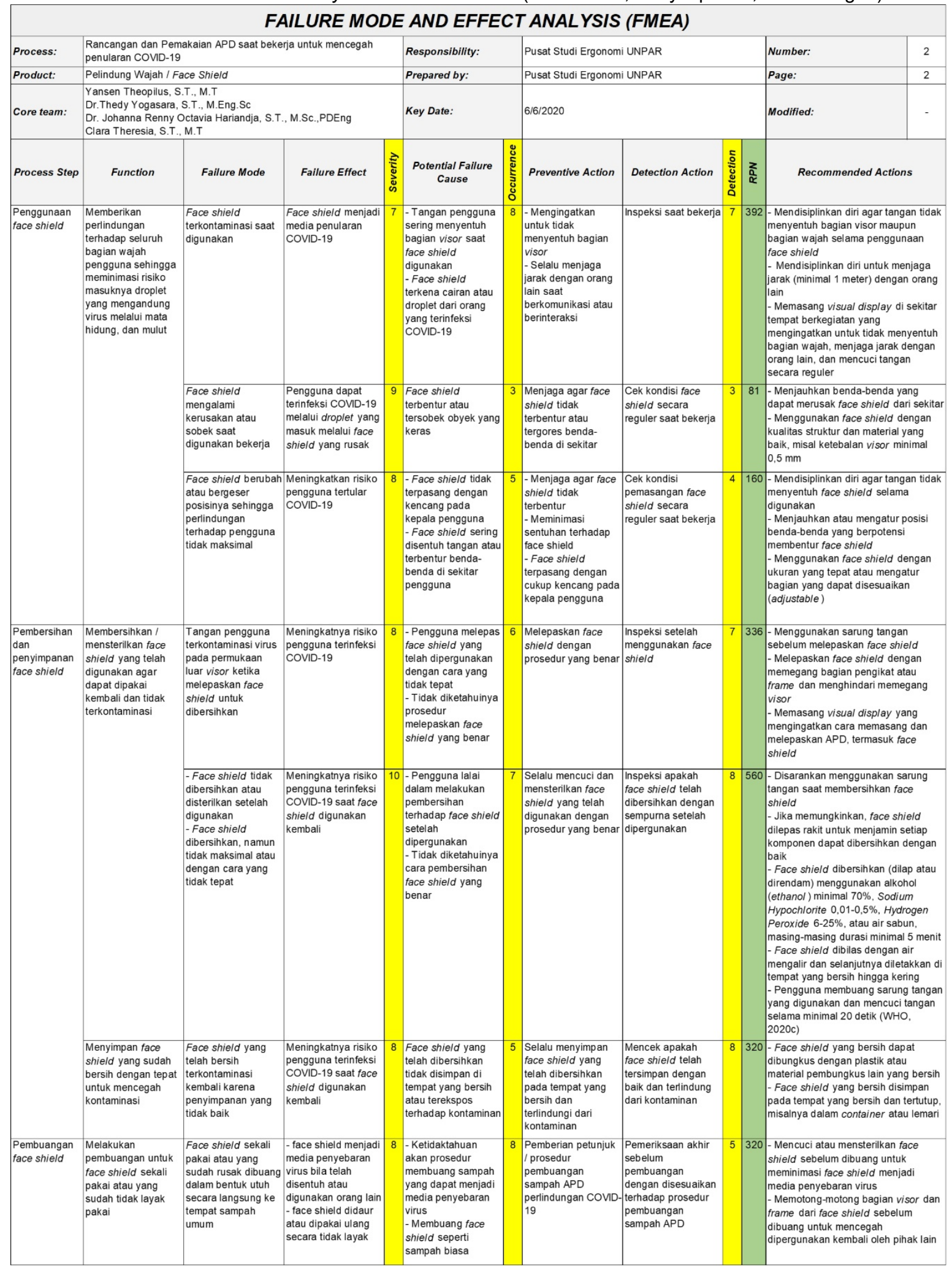




\section{Sarung Tangan (Hand Gloves)}

Sarung tangan merupakan sebuah produk yang dapat dipakai (wearable product) yang berfungsi untuk menyelubungi permukaan tangan manusia. Sarung tangan memiliki fungsi utama untuk melindungi tangan manusia dari paparan sesuatu dari lingkungan, seperti angin, panas, debu, kuman, virus, dan lain-lain.

Dalam kaitannya dengan perlindungan terhadap COVID-19, pemakaian sarung tangan berfungsi sebagai APD untuk menghindari paparan droplet / virus yang terdapat pada benda-benda yang disentuh oleh tangan dan juga menghindari transmisi virus dari tangan ke benda-benda yang disentuh yang dapat menginfeksi orang lain. Paparan virus pada tangan cukup berbahaya karena manusia sering kali menyentuh bagian wajah dengan tangan secara sengaja maupun tidak, sehingga berpotensi terpapar virus.

Tidak semua sarung tangan yang ada di pasaran dapat digunakan sebagai APD perlindungan terhadap COVID-19. Kriteria sarung tangan untuk perlindungan terhadap COVID-19 yang efektif adalah:

1. Menggunakan material yang tidak menyerap air dan memiliki pori-pori yang cukup kecil untuk tidak meloloskan cairan ke bagian dalam sarung tangan.

2. Menyelubungi permukaan tangan secara menyeluruh agar melindungi seluruh permukaan tangan.

Berdasarkan kriteria yang efektif sebagai APD COVID-19, sarung tangan dapat dibagi berdasarkan kemampuan pakainya menjadi sarung tangan sekali pakai (disposable) dan sarung tangan pemakaian berulang (reusable).

Terdapat 3 jenis material sarung tangan sekali pakai yang umum di Indonesia, yaitu sarung tangan plastik, sarung tangan nitril, dan sarung tangan lateks. Sarung tangan plastik memiliki harga yang sangat terjangkau dan cukup efektif dalam menahan partikulat dari luar. Namun, sarung tangan plastik cenderung mudah sobek. Sarung tangan nitril dan lateks merupakan jenis yang paling ampuh untuk menahan berbagai senyawa kimia dan partikulat lainnya (Argonne National Laboratory, 2014). Biasanya kedua jenis sarung tangan ini diperuntukkan bagi pekerja di bidang kesehatan atau yang berhubungan dengan bahan kimia, namun kedua jenis sarung tangan ini jauh lebih mahal dari sarung tangan plastik.
Selain itu, sarung tangan lateks mengandung bedak pada bagian dalam, sehingga dapat menimbulkan alergi terhadap penderita dermatitis (Health and Safety Executive, 2020a). Maka, penelitian ini mengkaji sarung tangan plastik sebagai sarung tangan yang efektif dan terjangkau bagi pekerja informal. Gambar ketiga jenis sarung tangan sekali pakai terdapat pada Gambar 5.

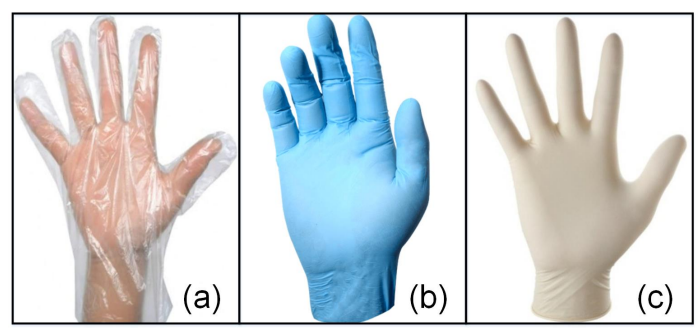

Gambar 5. Sarung Tangan Sekali Pakai (a) Plastik; (b) Nitril; (c) Lateks

(Sumber: www.amazon.in; www.graha multisarana.com; www.omnisurge.co.za )

Sarung tangan pemakaian berulang yang umum di pasar Indonesia dan memenuhi dua kriteria perlindungan COVID-19 adalah sarung tangan kain, sarung tangan karet (PVC/Silikon), dan sarung tangan kulit. Material sarung tangan kain terbatas pada jenis yang kedap air atau berpori kecil seperti kain nilon, katun, neoprene, dan lain-lain. Dari ketiga jenis sarung tangan tersebut, material kulit (asli maupun sintetis) relatif lebih mahal untuk digunakan dalam pekerjaan sehari-hari dan lebih sulit dibersihkan. Maka, penelitian ini mengkaji sarung tangan kain dan karet yang efektif dan terjangkau bagi pekerja informal. Ketiga jenis sarung tangan pemakaian berulang dapat dilihat pada Gambar 6.



Gambar 6. Sarung Tangan Pemakaian Berulang

(a) Kain; (b) Karet; (c) Kulit

(Sumber: www.dhgate.com; www.bandmanco.com; www.mafepe.com)

Sama seperti APD lain, sarung tangan juga memiliki risiko. Analisis risiko sarung tangan serta usulan aksi untuk mengatasinya terdapat pada Tabel 8 dan 9 . 
Tabel 8. Failure Mode and Effect Analysis APD Sarung Tangan (Rancangan dan Persiapan Pemakaian)

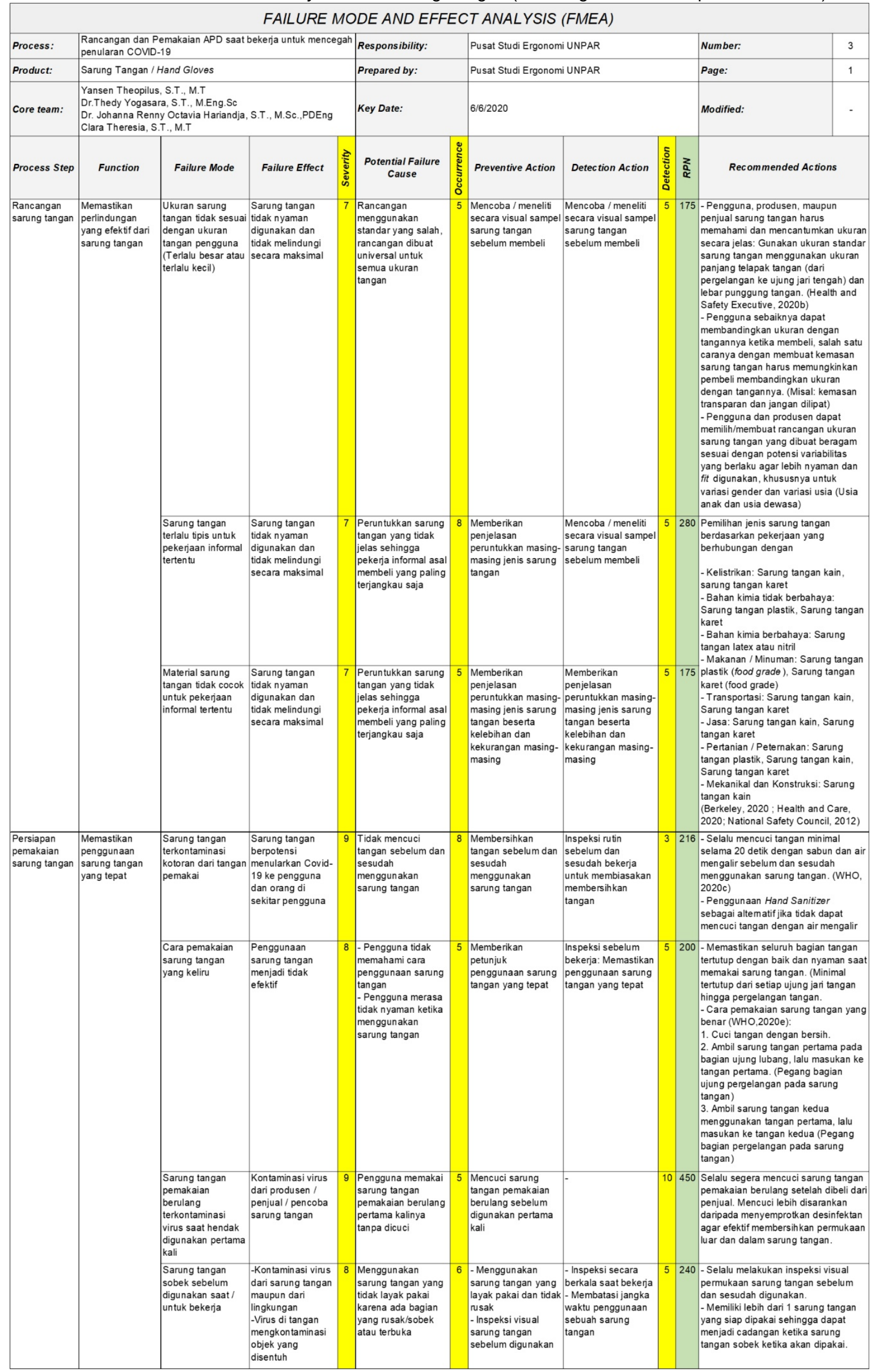


DOI: https://doi.org/10.26593/irsi.v9i2.4002.115-134

Tabel 9. Failure Mode and Effect Analysis APD Sarung Tangan (Pemakaian, Penyimpanan, Pembuangan)

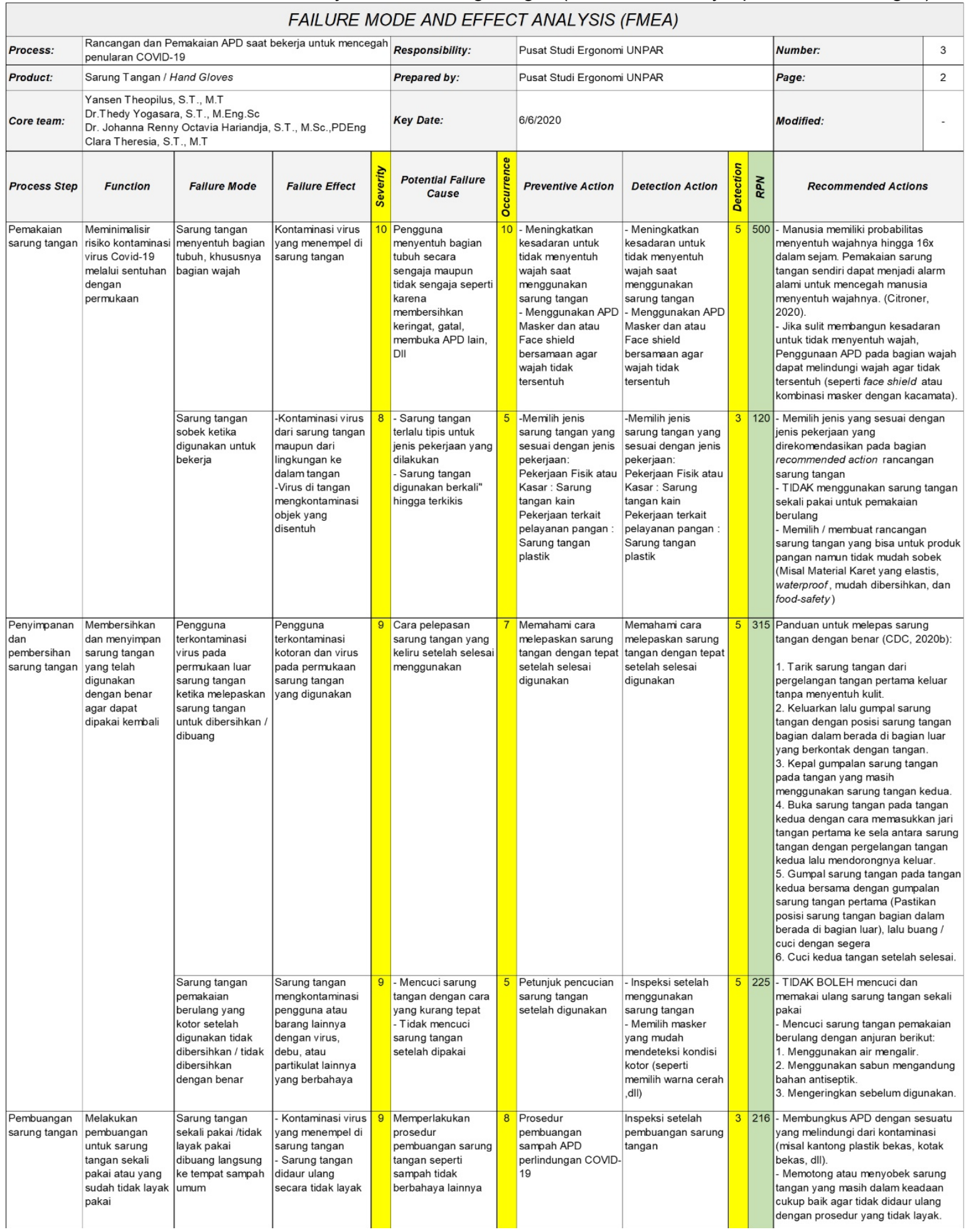


Berdasarkan analisis FMEA sarung tangan, terdapat 12 potensi risiko yang perlu diperhatikan pada rancangan dan proses penggunaannya. Dari 11 risiko tersebut, tiga risiko dengan RPN terbesar adalah risiko sarung tangan menyentuh bagian wajah saat bekerja $(\mathrm{RPN}=500)$, sarung tangan terkontaminasi ketika hendak digunakan pertama kali $(\mathrm{RPN}=450)$, dan kontaminasi sarung tangan ketika dilepaskan untuk dibersihkan / dibuang (RP N=315). Risiko tangan menyentuh wajah sering sekali terjadi ketika beraktivitas, dan berbahaya apabila sarung tangan yang terpapar virus menyentuh wajah sendiri. Maka, diperlukan pencegahan dengan cara selalu mawas diri atau memakai APD seperti face shield untuk mencegah tangan menyentuh area wajah. Risiko sarung tangan terkontaminasi saat penggunaan pertama kali sering kali terjadi karena sebagian orang Indonesia tidak suka mencuci sarung tangan setelah dibeli. Karena kita tidak bisa memastikan penjual memastikan kebersihan sarung tangan, maka sebaiknya kita selalu mencuci sarung tangan sebelum dipakai pertama kalinya. Risiko kontaminasi sarung tangan saat melepas sarung tangan juga sering kali terjadi dan punya potensi bahaya yang tinggi karena sarung tangan yang sudah dipakai dapat terpapar virus atau partikulat lainnya. Maka dari itu, cara melepas sarung tangan yang benar (panduan melepas sarung tangan yang tepat dapat dilihat pada Tabel 9) dan pembersihan tangan setelahnya sangat penting untuk diperhatikan.

Seluruh risiko pada APD sarung tangan memiliki tingkat severity di atas 7 yang menunjukkan bahwa risiko yang terjadi akan memberikan dampak yang berbahaya bagi pengguna. Beberapa risiko yang mudah dideteksi dapat dicegah dengan mudah, seperti mencuci tangan dengan air mengalir dan sabun sebelum dan sesudah menggunakan sarung tangan, memilih jenis sarung tangan yang tepat (panduan pemilihan pada Tabel 9), tidak menggunakan sarung tangan sekali pakai berkali-kali, serta memakai dan melepas sarung tangan dengan cara yang benar. Pemilihan jenis sarung tangan yang tepat juga berperan besar mengatasi berbagai risiko sarung tangan (panduan pemilihan sarung tangan yang tepat dapat dilihat pada Tabel 9), dimana pemilihan dilakukan berdasarkan jenis pekerjaan.

\section{Kesimpulan}

Berdasarkan hasil penelitian, masker memiliki 2 risiko rancangan, 2 risiko persiapan, 3 risiko pemakaian, 2 risiko penyimpanan, dan 1 risiko pembuangan. Risiko prioritas yang perlu diperhatikan pada masker adalah pelepasan masker di tempat umum, masker tidak dibersihkan dengan baik setelah digunakan, dan pembuangan masker yang keliru. Produk face shield memiliki 5 risiko rancangan, 3 risiko persiapan, 3 risiko pemakaian, 3 risiko penyimpanan, dan 1 risiko pembuangan. Risiko prioritas produk face shield adalah face shield tidak dibersihkan dengan baik setelah digunakan, dimensi visor tidak sempurna menutup wajah, dan face shield mengontaminasi pengguna saat digunakan. Pada produk sarung tangan, terdapat 3 risiko rancangan, 4 risiko persiapan, 2 risiko pemakaian, 2 risiko penyimpanan, dan 1 risiko pembuangan. Risiko prioritas sarung tangan yang perlu diperhatikan adalah sarung tangan menyentuh bagian wajah saat bekerja, sarung tangan terkontaminasi ketika digunakan pertama kali, dan sarung tangan mengontaminasi tangan ketika dilepaskan. Seluruh risiko prioritas yang disebutkan tidak hanya memiliki severity yang tinggi, namun juga sering dilakukan pekerja informal ketika bekerja dan sulit dihindari dalam kegiatan sehari-hari.

Analisis FMEA terhadap APD pencegah penularan COVID-19 menghasilkan cukup banyak risiko yang berpotensi membahayakan para pekerja informal dalam menghadapi kehidupan normal yang baru, dimana setiap orang perlu meningkatkan awareness terhadap potensi paparan virus. Pemakaian APD masker, face shield, dan sarung tangan memang sudah biasa dilakukan oleh pekerja pada sektor tertentu, seperti tenaga medis atau pekerja di lab kimia, namun hal ini sangat baru bagi para pekerja di sektor informal. Ketika berhadapan dengan sesuatu yang baru, maka sangat penting bagi seseorang untuk memahami potensi risiko yang ada agar terhindar dari hal-hal yang tidak diinginkan.

Berdasarkan pembahasan penelitian, kita mengetahui bahwa penggunaan masker, face shield, dan sarung tangan sangat penting dalam mencegah penularan COVID-19, maka seluruh pekerja informal disarankan untuk menggunakan. Namun, terdapat pengecualian apabila terdapat kondisi tertentu dimana 
pekerja sulit menggunakan ketiga APD tersebut. Sebagai contoh, sulit bagi driver ojek untuk menggunakan face shield bersamaan dengan helm, sulit bagi penerjemah tunarungu untuk menggunakan masker kain, dan lain-lain.

Kajian pada penelitian ini memaparkan manfaat, risiko, dan rekomendasi solusi pencegahan untuk risiko teridentifikasi agar pembaca dan pekerja informal memahami bahwa ketiga jenis APD ini benar dapat melindungi mereka, namun punya potensi risiko. Oleh karena itu, kajian ini berkontribusi memberikan pengetahuan mengenai keuntungan pemakaian APD dan bagaimana mencegah potensi risikonya agar para pekerja informal bukan hanya efektif terhindar dari paparan COVID-19, tapi juga memastikan kesehatan dan keselamatannya dalam bekerja.

Ketika orang sudah memahami manfaat dan risiko terhadap sesuatu, maka mereka akan percaya diri dan tidak merasa takut. Dalam rangka pencegahan dan penanggulangan pandemi COVID-19, kajian manfaat dan risiko seperti pada penelitian ini dapat dilakukan juga terhadap produk atau proses lainnya, seperti produk pembersih (sanitizer atau disinfectant), produk bilik sterilisasi, proses pembatasan sosial, proses Work From Home (WFH), dan lain-lain. Tujuannya adalah untuk memastikan bahwa produk dan proses perlawanan COVID19 tersebut memang memiliki manfaat yang nyata dan risiko yang dapat dikendalikan. Dengan demikian, manusia semakin siap dalam menggunakan produk dan proses perlindungan yang tidak biasa mereka gunakan.

Pada penelitian ini, analisis risiko APD pencegah penularan COVID-19 menggunakan konteks dan situasi pekerja informal secara umum di Indonesia. Hasil penelitian ini dapat didukung dengan tambahan data empiris seperti wawancara atau observasi langsung ke beberapa daerah untuk mendapatkan input tambahan dari pemilik masalah mengenai situasi pekerja informal yang dapat dikaitkan dengan risiko pemakaian APD. Analisis risiko pada penelitian ini juga menggunakan metode FMEA dimana penentuan tingkat severity, occurrence, dan detection yang dihasilkan dilakukan secara subjektif. Hasil penelitian ini dapat dilengkapi dengan metode lainnya yang lebih objektif atau melibatkan berbagai pihak dari sudut pandang yang beragam dalam menganalisis nilai prioritas risiko (RPN) dari masing-masing potensi risiko yang muncul.

\section{Daftar Pustaka}

Argonne National Laboratory, FACT Sheet Glove Selection, [Online], Diakses dari: https://www.aps.anl.gov/files/APS-Uploads/ Safety-and-Training/Safety/Reference-Material/glove-selection.pdf [2020, 13 Juni].

Badan Perencanaan Pembangunan Nasional. (2009). Peran Sektor Informal Sebagai Katup Pengaman Masalah Ketenagakerjaan. Jakarta: BPPN.

Badan Pusat Statistik. (2020). Pertumbuhan Ekonomi Indonesia Triwulan I-2020. Jakarta: BPS.

Berkeley, Glove Selection Guide, [Online], Diakses dari: https://ehs.berkeley.edu/ workplace-safety/glove-selection-guide [2020, 13 Juni].

Centers for Disease Control and Prevention (2013). Workplace Safety \& Health Topics. Eye Protection for Infection Control, [Online], Diakses dari: http://www.cdc.gov/niosh/ topics/eye/eye-infectious.html [2020, 10 Juni].

Centers for Disease Control and Prevention, Coronavirus Disease 2019 (COVID-19). How to Protect Yourself \& Others, [Online], Diakses dari: https://www.cdc.gov/ coronavirus/2019-ncov/prevent-gettingsick/prevention-H.pdf [2020a, 10 Juni].

Centers for Disease Control and Prevention, How to Remove Gloves, [Online], Diakses dari: https://www.cdc.gov/vhf/ebola/pdf/pos ter-how-to-remove-gloves. pdf?fbclid=IwAR 0i5PeHnaG7yjcO99Guf6jL2vgbUtsGJz2cna -3gR2NKLsYLzdUFOWnYcY [2020b, 13 Juni].

Citroner, G., You Probably Touch Your Face 16 Times an Hour: Here's How to Stop, [Online], Diakses dari: https://www.health line.com/health-news/how-to-not-touchyour-face [2020, 13 Juni].

Esposito, S., Principi, N., Leung, C.C., \& Migliori, G.zB. (2020). Universal Use of Face Masks for Success Against COVID-19: Evidence and Implications for Prevention Policies. European Respiratory Journal, 1, 3-6.

Food and Drug Administration (2020). N95 Respirator, Surgical Masks and Face Masks, [Online], Diakses dari: https://www. fda.gov/medical-devices/personal-protective-equipment-infection-control/n95-respi- 
rators-surgical-masks-and-face-masks\#s2 [2020, 15 Juni].

Gorbalenya, A. E., Baker, S.C., Baric, R. S., de Groot, R. J., Drosten, C., Gulyaeva, A. A., Haagmans, B. L., Leontovich, A. M., Neuman, B. W., Penzar, D., Perlman, S., Poon, L. L. M., Samborskiy, D., Sidorov, I. A., Sola, A., \& Ziebuhr, J. (2020). Severe Acute Respiratory Syndrome-related Coronavirus: The Species and Its Viruses A Statement of The Coronavirus Study Group. Nature Microbiology, 5, 536-544.

Gugus Tugas COVID-19, Data Sebaran COVID-19, [Online], Diakses dari: https://covid19.go.id/ [2020a, 18 Juni].

Gugus Tugas COVID-19. Data Sebaran COVID-19, [Online], Diakses dari: https://covid19.go.id/p/protokol [2020b, 8 Juni].

Harapan, H., Itoh, N., Yufika, A., Winardi, W., Keam, S., Te, H., Megawati, D., Hayati, Z., Wagner, A. L., \& Mudatsir, M. (2020). Coronavirus Disease 2019 (COVID-19): A Literature Review. Journal of Infection and Public Health, 13(5), 667-673.

Health and Care, Which Gloves Material Should I Choose?, [Online], Diakses dari: https:// www.workwear.co.uk/blog/which-glove-material-should-i-choose.html [2020, 13 Juni].

Health and Safety Executive, Gloves: Choosing The Right Gloves to Protect Skin, [Online], Diakses dari: https://www.hse.gov.uk/mvr/ topics/gloves.htm [2020a, 13 Juni].

Health and Safety Executive, Glove Sizes Measuring Your Hand, [Online], Diakses dari: https://www.hse.gov.uk/skin/employ/ glove-sizes.htm [2020b, 13 Juni].

International Labour Organization (2020). In The Face of A Pandemic: Ensuring Safety and Health at Work. Geneva: ILO.

Karyaone (2020), Beberapa Tipe Face Shield untuk Melindungi Diri dari Virus Corona, [Online], Diakses dari: https://www.karyaone .co.id/blog/tipe-face-shield/ [2020, 7 Juni].

Kementerian Kesehatan Republik Indonesia (2020a). Surat Edaran Nomor HK.02.01/MENKES/335/2020 Tentang Protokol Pencegahan Penularan COVID-19 di Tempat Kerja Sektor Jasa dan Perdagangan (Area Publik) dalam Mendukung Keberlangsungan Usaha. Jakarta: Republik Indonesia.

Kementerian Kesehatan Republik Indonesia. (2020b). Surat Edaran Nomor
HK.01.07/MENKES/328/2020 Tentang Panduan Pencegahan dan Pengendalian COVID-19 di Tempat Kerja Perkantoran dan Industri dalam Mendukung Keberlangsungan Usaha pada Situasi Pandemi. Jakarta: Republik Indonesia.

Keppres (2020). Keputusan Presiden Republik Indonesia Nomor 7 Tahun 2020 tentang Gugus Tugas Penanganan COVID-19. Jakarta: Republik Indonesia.

Lindsley, W. G., Noti, J. D., Blachere, F. M., Szalajda, J. V., \& Beezhold, D. H. (2014). Efficacy of Face Shields Against Cough Aerosol Droplets from a Cough Simulator. Journal of Occupational and Environmental Hygiene, 11(8), 509-518.

Manuele, F. A. (2008). Advanced Safety Management. New Jersey: John Wiley \& Sons Inc.

National Safety Council, Safety at Hand: Use The Right Glove for Proper Protection, [Online], Diakses dari: https://www.safety andhealthmagazine.com/articles/safety-athand-use-the-right-glove-for-proper-protection-4 [2020, 13 Juni].

Pemerintah Republik Indonesia (2020). Peraturan Pemerintah Nomor 21 Tahun 2020 tentang Pembatasan Sosial Berskala Besar Dalam Rangka Percepatan Penanganan Coronavirus Disease 2019 (COVID-19). Jakarta: Republik Indonesia.

Perencevich, E. N., Diekema, D. J., \& Edmond, M. B. (2020). Moving Personal Protective Equipment into The Community: Face Shields and Containment of COVID-19. JAMA. 323(22), 2252-2253.

Ravenscroft, T. (2020), Eight Face Shields Designed to Protect Corona Virus Healthcare Workers. Dezeen. [Online], Diakses dari: https://www.dezeen.com/2020 /04/13/face-shields-coronavirus-applefoster/ [2020, 9 Juni].

Roberge, R. J. (2016). Face Shields for Infection Control: A Review. Journal of Occupational and Environmental Hygiene, 13(4), 235-242.

Shakya, K. M., Noyes, A., Kallin, R., \& Peltier, R. E. (2016). Evaluating The Efficacy of Cloth Facemasks in Reducing Particulate Matter Exposure. Journal of Exposure Science \& Environmental Epidemiology, 27 (3), 352-357.

Shereen, M. A., Khan, S., Kasmi, A., Bashir, N., \& Siddique, R. (2020). COVID-19 Infection: 
Origin, Transmission, and Characteristics of Human Coronaviruses. Journal of Advanced Research, 24, 91-98.

World Health Organization, WHO Coronavirus Disease (COVID-19) Dashboard, [Online], Diakses dari: https://covid19. who.int/?gclid= CjOKCQjwoPL2BRDxARIsAEMm9y_SgyYI34pvGeOELLPw4QQZM9nnugUYKmGO CQgVCA1tmYAEzcpp3laAnKREALw_wcB [2020a, 18 Juni].

World Health Organization, WHO Timeline COVID-19, [Online], Diakses dari: https://www.who.int/news-room/detail/2704-2020-who-timeline---covid-19 [2020b, 8 Juni].

World Health Organization, Coronavirus Disease (COVID-19) Advice for The Public: When and How to Use Mask [Online], Diakses dari: https://www.who.int/ emergencies/disease/novel-coronavirus2019/advice-for-public/when-and-how-touse-masks [2020c, 10 Juni 2020].

World Health Organization, Rational Use of Personal Protective Equipment for Coronavirus Disease 2019 (COVID-19), [Online], Diakses dari: https://apps.who.int /iris/handle/10665/331498 [2020d, 10 Juni].

World Health Organization, Glove Use Information Leaflet, [Online]. Diakses dari: https://www.who.int/gpsc/5may/Glove_Use _Information_Leaflet.pdf [2020e, 13 Juni].

Worldometer, Covid-19 Coronavirus Pandemic Data, [Online], Diakses dari: https://www. worldometers.info/coronavirus/ [2020, 18 Juni].

Yang, K. \& El-Haik, B. S. (2009). Design for Six Sigma: A Roadmap for Product Development $\left(2^{\text {nd }}\right.$ ed.). New York: McGrawHill.

https://www.amazon.in/Plastic-Gloves-Disposable-100pcs-12/dp/B00L39P4OY [2020, 13 Juni].

https://www.amazon.in/3M-Particulate-Respirator-8210-N95-Mask/dp/B003B39QEO [2020, 15 Juni]. http://antropometriindonesia.org/[2020,15 Juni]. https://bandmanco.com/product/long-wrist-nylon-gloves/ [2020, 13 Juni].

https://www.coccare.com/product/medical-visors-face-shield-maskmedical-protectivemaskprotective-face-shield/ [2020, $10 \mathrm{Juni}]$. https://www.dhgate.com/product/householdcleaning-gloves-for-fruit-dishwashing/416014682.html\#seo=WAP [2020, 13 Juni].

https://www.fda.gov/medical-devices/personalprotective-equipment-infection-control/facemasks-and-surgical-masks-covid-19-manufacturing-purchasing-importing-and-donating-masks-during [2020, 15 Juni].

https://grahamultisarana.com/product/devall-hiprotection-blue-nitrile-glove/ [2020, 13 Juni]. https://www.halodoc.com/alasan-masker-kainsebaiknya-tidak-dipakai-lebih-dari-4-jam [2020, 15 Juni].

https://www.lazada.co.id/products/eceran-masker-scuba-masker-korea-masker-scuba-korea-masker-kain-masker-sensi-masker-murah-i1163516193.html [2020, 15 Juni].

https://www.mafepe.com/en/uro-15negreleather-gloves [2020, 13 Juni].

https://www.merdeka.com/foto/peristiwa/11825 73/20200601144949-new-normal-pedagang-pasar-wajib-pakai-face-shield-hinggasarung-tangan-001-nfi.html [2020, 18 Juni]. https://mollyssarasota.com/products/ssh-blkheart [2020, 10 Juni].

https://obscape.com/site/faceshield-instruction s/ [2020, 13 Juni].

https://omnisurge.co.za/shop/surgical-sterilepowder-free-latex-gloves/ [2020, 13 Juni]. https://support.apple.com/en-us/HT211142 [2020, 13 Juni].

https://ufuncase.com/products/disposable-face -shield-1 [2020, 10 Juni].

https://www.wish.com/product/protection-hatanti-saliva-anti-spitting-splash-fog-uv-hatwith-face-shield [2020, 10 Juni]. 
DOI: https://doi.org/10.26593/irsi.v9i2.4002.115-134

Halaman ini sengaja dikosongkan.

This page is intentionally left blank. 